\title{
Agrotourism as an element of the development of a green economy in a resort area
}

\author{
Alla Baranova ${ }^{1, *}$ and Svetlana Kegeyan ${ }^{1}$ \\ ${ }^{1}$ Sochi State University, Sochi, Sovetskaya st., 26a, 354000, Russia
}

\begin{abstract}
Due to the deterioration of the environmental situation in the world, many countries are interested in a strategy of "green growth" that combines efforts in the field of economics, ecology, sociology, health care, and technology. One of the environmentally friendly activities is agrotourism. Russian regions have a huge natural and recreational potential for agrotourism, which has a high socio-economic importance for municipalities in terms of the development of small and medium-sized businesses, the creation of additional jobs, the formation of the added value of the tourist product. However, there are negative factors: low level of infrastructure development, lack of a recognizable brand, poor transport accessibility to the objects of agrotourism, seasonality of agricultural products, weak state financial support for the development of entrepreneurship in rural areas, lack of investors' interest. The paper presents main features of the development of agrotourism in the resort area (for example, the resort city of Sochi) that has the properties of a "green economy" and can contribute to "green growth".
\end{abstract}

\section{Introduction}

In order to assert confidently that agrotourism is an environmentally friendly direction of "green growth", we will consider its place in the green economy of the resort territory. As a result of studying the works of economists, we found out that the green economy is:

1) the direction in which the economy is considered to be a dependent component of the natural environment and is part of it [1];

2) synergism of four levels of development: economic growth, social well-being, environmental protection and human health. The development of a green economy will create new productive jobs, reduce poverty, minimize carbon dependence and prevent further destruction of ecosystems [2];

3 ) an economy aimed at preserving the well-being of society through the efficient use of natural resources, as well as ensuring the return of end-use products to the production cycle [3]

4) an economy relying on resource-saving and environmentally friendly production, increases people's well-being and reduces environmental risks [4].

Experts for the implementation of plans for the transition to a green economy identify the following priority areas [5]:

\footnotetext{
* Corresponding author: baranovalla-77@mail.ru
} 
- the use of alternative sources of energy and fuel;

- rational use of drinking water and natural resources;

- proper waste disposal;

- development of agriculture in terms of improving soil fertility, growing organic products;

- increasing employment to reduce unemployment and eliminate poverty, etc.

From our point of view, it is necessary to add the development of tourism. Tourism is not just a travel. It is a collective and multifaceted concept that includes various areas of human activity and behavior (cognitive aspect, education, rehabilitation and treatment, the study of flora and fauna, etc.); each of them has its own scientific concept. In this regard, the article presents a systematic approach to the development of agrotourism.

\section{Methods}

The methods of logical and statistical analysis, synthesis, and observation were the basis of the study. Authors (Grineva M.N., Ryndach M.A., Adamesku A.A., Voskresensky V.Yu., Trukhachev A.V., Zdorov M.A., Sh. Filip, K. Hunter and K. Blackstock and others) presented in their works the problems and prospects of agrarian tourism through the provision of production in rural areas (farming). On the basis of the official statistical information of the resort city of Sochi, we have ratiocinated the possibility and necessity of developing agrotourism at the resort.

\section{Results}

Studying the features of agrotourism, we found out that most of the authors identify it in meaning with rural tourism.

"Rural tourism is the organization activity of recreation for tourists in rural areas or in small cities (with no industrial zones and buildings) with the provision of hospitality services in the private sector with the possibility of labor participation (agritourism), focused on the use of natural, cultural historical and other resources that are traditional for a given area "[6];

"Agritourism is a type of recreational tourism and an active form of recreation in rural areas, which is organized exclusively by local residents. There are five criteria agro-tourism: the use of natural resources; no damage to the habitat, i.e. environmental friendliness; environmental education and awareness; preservation of the local socio-cultural sphere; economic efficiency and sustainable rural development"[7].

"Agrarian tourism is a type of economic activity on the use of natural, cultural, historical and other resources in the countryside to create a complex tourist product when a host family accommodates tourists on agricultural farms" [8].

"Agrarian tourism should be understood first of all as the entrepreneurial activity of tourist companies and the rural population in attracting guests to rural areas in order to rest and acquire skills in learning folk crafts, participating in various types of rural activities as well as in selling services and local products "[9].

"Agrotourism is a type of tourism in which the main motivation is a recreation in rural areas, traditional enculturation prevailing in natural rural areas accompanied by comprehensive services for accommodation, meals, excursion services, organization of leisure and sporting events, organization of fishing, hunting, the acquisition of knowledge and skills of rural labor and technology"'[10].

Other authors, for example, Zdorov MA and Trukhachev A.V. Clearly separate the concepts of "rural tourism" and "agrotourism." Taking into account their opinions 
agrotourism is a type of tourism the motivation of which is the production of agricultural products, but not necessarily in the countryside.

Agrotourism is a related branch of agriculture providing employment for the rural population and the attracted contingent to increase the main production and personal incomes of citizens with elements of rest and recreation [11].

Agrotourism is a subspecies of rural tourism implemented for the purpose of recreation, education, and active involvement in traditional forms of management with the active use of factors of agricultural activity. Its main features are: the involvement of tourists in agricultural activities (agricultural production) [12].

In foreign authors' opinion, agrotourism is an agricultural activity of farmers. For example, S. Philip, K. Hunter and K. Blackstock agrotourism explained as three components: accommodation of tourists for the purpose of rest on a decorative (not functioning) farm; accommodation on a working farm without participation in production (organizing weddings, horse riding, etc.); accommodation on a working farm with involvement in agriculture (production) [13]. T. Kizos and T. Iosifides talk about the need to develop competition between farmers [14].

Having studied the opinions of the authors, it is necessary to consider agrotourism from the point of view of a green economy as trips of citizens for the purpose of communion with nature through participation in plant growing, fish farming, beekeeping, and animal husbandry. The agricultural industry is an integral part of the resorts, which as a therapeutic and health-improving and specially protected area, possessing natural healing resources and the buildings and facilities necessary for their operation must have only environmentally friendly infrastructure.

\section{Discussion}

The resort city of Sochi as a year-round balneological resort, which is a part of the Caucasian Biosphere Reserve, is focused on meeting the needs of the population and tourists for fresh vegetables, fruits, tea, beekeeping and floriculture products, poultry meat and the cultivation of trout fish.

The municipal program "Development and support of agriculture in the city of Sochi" operates on the territory of the city of Sochi - Resolution of the Administration of the City of Sochi of 11.12.2015, No. 3493, in accordance with which the total funding for this industry in 2017 amounted to 20.4 million rubles. , including: funds of the federal budget -2.4 million rubles. (11.8\%), budget funds of the Krasnodar Territory -8.2 million rubles. $(40.7 \%)$, the funds of the budget of the city of Sochi -9.7 million rubles. $(47.5 \%)$.

The main tasks of the city:

- increasing the role of the agricultural sector;

- improving the forms of organization of land and property relations;

- support for entrepreneurship;

- the introduction of modern technology;

- improvement of forms of state support;

- regulation of the price mechanism;

- development of market infrastructure, cooperation, integration and innovative measures.

The development of the agro-industrial complex of the city of Sochi is provided in the following areas:

1) the construction of greenhouses for the production of greenhouse vegetables;

2) the development of the tea industry;

3) the development of fish farming and aquaculture;

4) the creation of new agro tourism routes;

5) the laying of gardens. 
The subjects of the Sochi agro-industrial complex are small forms of management in the form of personal subsidiary farms, peasant farms and individual entrepreneurs $40 \%$ of them are profitable over the past 5 years (table 1).

Table 1. The volume of agricultural production and the payment of a single agricultural tax (SAT) (thousand rubles).

\begin{tabular}{|l|c|c|c|c|c|}
\hline \multicolumn{1}{|c|}{ Indicators } & $\mathbf{2 0 1 3}$ & $\mathbf{2 0 1 4}$ & $\mathbf{2 0 1 5}$ & $\mathbf{2 0 1 6}$ & $\mathbf{2 0 1 7}$ \\
\hline $\begin{array}{l}\text { Households of all } \\
\text { categories, total number }\end{array}$ & 2117685 & 2215173 & 2236983 & 2528045 & $2559400^{*}$ \\
\hline $\begin{array}{l}\text { Agricultural } \\
\text { organizations }\end{array}$ & 385659 & 231995 & 194567 & 245405 & no information \\
\hline Households (citizens) & 1731247 & 1982101 & 2040892 & 2281192 & no information \\
\hline $\begin{array}{l}\text { Peasant (farmer) farms } \\
\text { and individual } \\
\text { entrepreneurs }\end{array}$ & 779 & 1077 & 1524 & 1448 & no information \\
\hline $\begin{array}{l}\text { Single agricultural tax } \\
\text { (SAT) }\end{array}$ & 5927 & 3005 & 3467 & 2494 & 6162 \\
\hline
\end{tabular}

* Information on the achievement of target indexes of the Socio-Economic Development Program of the city of Sochi for the period up to 2017 .

In the private sector, there are more than 25 thousand personal subsidiary farms and 226 peasant (farmer) farms. Graphically, the volumes of their production are presented in Fig. 1.

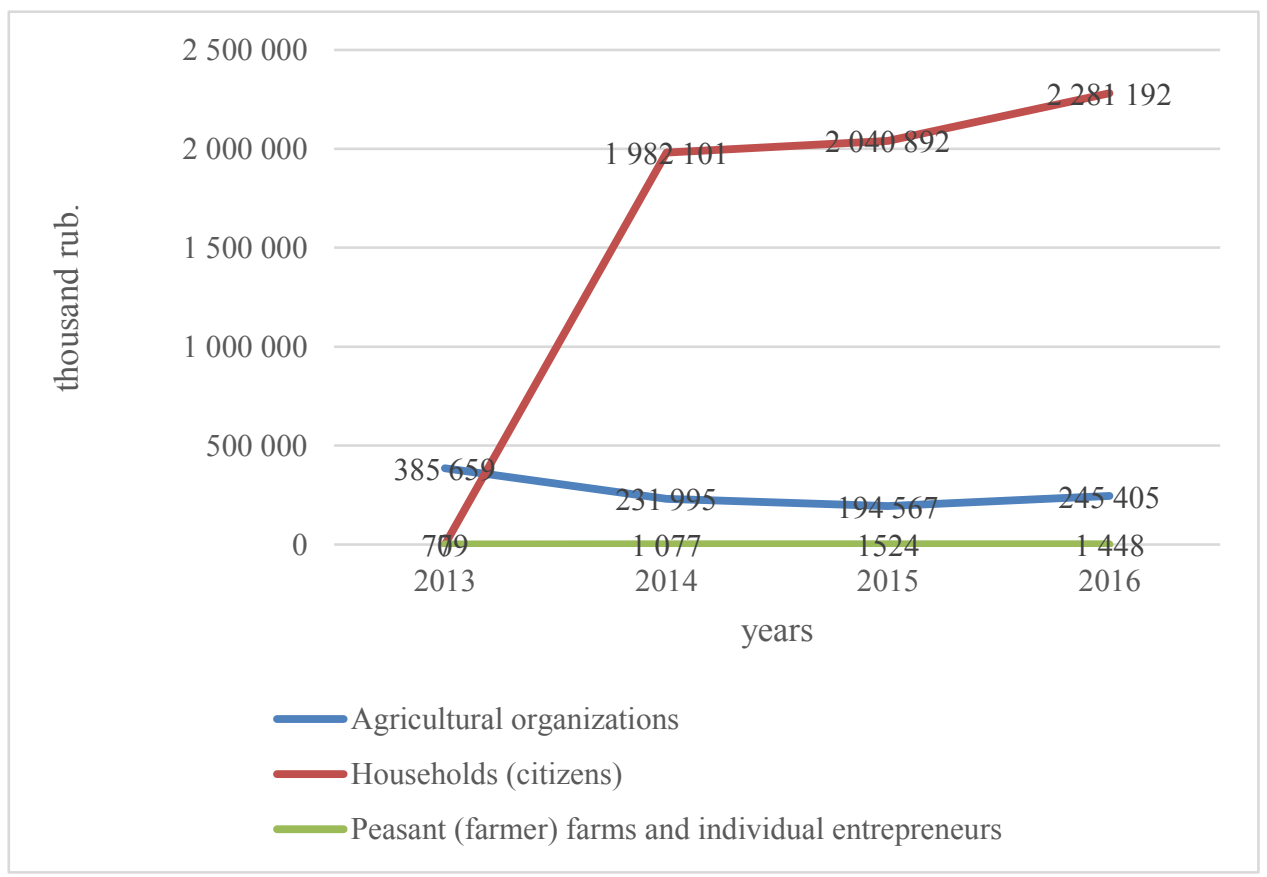

Fig. 1. The volume of agricultural production (compiled by the authors).

In accordance with the Plan of activities for the development of agricultural consumer cooperation in the territory of municipal units of the Krasnodar Territory for 2018-2019, creation of cooperatives (commercial or non-commercial) in resorts is planned (Table 2). 
Table 2. Target indexes for creating agricultural cooperatives in the resorts of the Krasnodar Territory.

\begin{tabular}{|c|c|c|c|c|c|c|c|c|}
\hline \multirow[t]{2}{*}{$\begin{array}{l}\text { Resort } \\
\text { name }\end{array}$} & \multirow[t]{2}{*}{$\begin{array}{l}\text { Resort } \\
\text { type }\end{array}$} & \multirow[t]{2}{*}{$\begin{array}{l}\text { Population, } \\
\text { thous. }\end{array}$} & \multirow{2}{*}{$\begin{array}{l}\text { Including } \\
\text { the rural } \\
\text { population } \\
\text { thousand } \\
\text { people }\end{array}$} & \multirow[t]{2}{*}{$\begin{array}{l}\text { Percentage } \\
\text { of rural } \\
\text { population }\end{array}$} & \multicolumn{2}{|c|}{$\begin{array}{l}\text { Number of } \\
\text { planned } \\
\text { cooperatives } \\
\text { (units) }\end{array}$} & \multicolumn{2}{|c|}{$\begin{array}{l}\text { Number of } \\
\text { shareholders } \\
\text { (people) }\end{array}$} \\
\hline & & & & & 2018 & 2019 & 2018 & 2019 \\
\hline $\begin{array}{l}\text { Total in the } \\
\text { region }\end{array}$ & - & 5571 & 2529 & 45 & 44 & 43 & $\begin{array}{c}25 \\
290\end{array}$ & $\begin{array}{l}101 \\
160\end{array}$ \\
\hline Anapa & Federal & 186 & 110 & 59 & 1 & 1 & 1108 & 4430 \\
\hline Gelendzhik & Federal & 115 & 41 & 36 & 1 & 0 & 406 & 1623 \\
\hline Sochi & Federal & 493 & 76 & 15 & 1 & 0 & 764 & 3055 \\
\hline Yeisk & Regional & 135 & 51 & 38 & 1 & 1 & 512 & 2049 \\
\hline $\begin{array}{c}\text { Goryachiy } \\
\text { klyuch }\end{array}$ & Regional & 65 & 23 & 35 & 1 & 1 & 282 & 1130 \\
\hline $\begin{array}{l}\text { Tuapse } \\
\text { district }\end{array}$ & Regional & 130 & 51 & 39 & 1 & 0 & 509 & 2034 \\
\hline Apsheronsk & Local & 101 & 33 & 33 & 1 & 1 & 333 & 1331 \\
\hline Temryuk & Local & 124 & 84 & 68 & 1 & 0 & 840 & 3359 \\
\hline $\begin{array}{c}\text { Primorsko- } \\
\text { Akhtarsk }\end{array}$ & Local & 59 & 26 & 44 & 1 & 0 & 275 & 1100 \\
\hline $\begin{array}{l}\text { Slavyansk- } \\
\text { on Kuban }\end{array}$ & Local & 132 & 66 & 50 & 1 & 1 & 665 & 2658 \\
\hline Labinsk & Local & 98 & 38 & 39 & 1 & 1 & 377 & 1506 \\
\hline
\end{tabular}

It should be clarified that despite the growth in the volume of agricultural production and payment of SAT there are problems in the industry:

1) the absence of specific investment projects;

2) limited pastures;

3) the need to ensure the irrigation of agricultural products in open and closed grounds and the overhaul of wooden greenhouses (replacement with iron);

4) the creation of social and living conditions of work;

5) lack of own current assets at the poultry farm;

6) a decrease in the production of trout fish due to the flooding of nursery ponds as a result of a natural disaster (heavy precipitation and mudflow);

7) plant disease, etc.

The city authorities are making efforts in the organization of agricultural fairs, the importation of products from areas of the Krasnodar Territory and other regions. Many entrepreneurs are switching to environmentally friendly areas of activity: growing vegetables in greenhouses, beekeeping, and the development of agro-tourism. But so far the resort lacks a systematic approach to the development of agritourism.

"The system being a philosophical category reflects not something separate and indivisible but the contradictory unity of the many and one that reflects the objective existence of specific individual interrelated sets of elements".

"A system is an entity that as a result of the interaction of its parts can maintain its existence and function as a whole. Characteristic of the system: interconnected parts function as a whole, emergent properties are inherent in the system, the relative position of the parts is crucial, changing the structure of the parts changes the behavior of the system; it is impossible to reduce the whole to the simple sum of its parts".

Figure 2 shows the system development model of agrotourism, consisting of five main blocks:

1. The management subsystem, including the management bodies that affect agrotourism through the issuance of regulations, the development of targeted programs and concepts. 
2. The scientific and educational subsystem provides the organization of agrotourism with personnel, conducts scientific research in this area.

3. Marketing subsystem and it is impossible to promote the products and services of agrotourism without it. Organizations can create their own websites, advertisements, and can address to travel companies.

4. The financial subsystem provides agrotourism organizations with financial resources both public and private.

5. Managed subsystem consisting directly of agrotourism organizations and the corresponding infrastructure (guest houses, manors, ethnic villages, etc.). The four subsystems listed above affect the fifth one. Depending on how well the managing, scientific, educational, marketing, and financial subsystem will work, the managed subsystem will show the result.

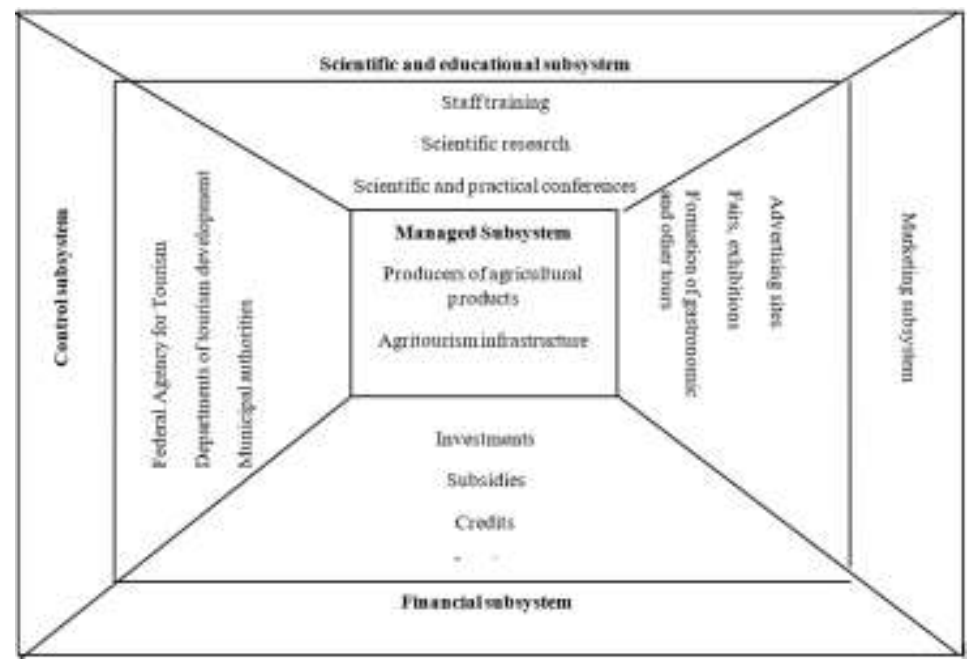

Fig. 2. Model of agrotourism system development (compiled by the authors).

\section{Conclusions}

Agritourism is not the most profitable economic activity in the resort. But the creation of an appropriate infrastructure for its development may attract even more tourists especially in spring and autumn when the sea is cold. Agritourism should not be understood only as the production of agricultural products. Agritourism is a wide range of activities, including gastronomic tours, education (training in plant cultivation, cooking), ethnographic tourism (learning about people's life and culture), eco-tourism (studying flora and fauna), and recreational (outdoor recreation).

\section{References}

1. T.V. Zaharova, Vestn. Tom. gos. un-ta. Ehkonomika 4(16), 131-134 (2011)

2. M.S. Egorova, Fundamental'nye issledovaniya 6(6), 82-83 (2014)

3. I.A. Rodionova, S.A. Lipina, Fundamental'nye issledovaniya 24(2), 40-46 (2015)

4. T. Gvarliani, E. Vorobei, 9th International conference on the mediterranean coastal environment, Medcoast 2009 1, 173-180 (2009) 
5. I.V. Lebedeva, S.L. Kopylova, Metodicheskoe posobie «Sel'skij turizm kak sredstvo razvitiya sel'skih territorij» (ANO «ARSI», Moskva, 2018)

6. M.N. Grineva, Vestnik FGBOU VPO «Voronezhskij gosudarstvennyj agrarnyj universitet imeni imperatora Petra I» 1(27), 60-67 (2013)

7. A.A. Adamesku, V.Yu. Voskresenskij, Regional'naya ehkonomika teoriya i praktika 33, 161-163 (2009)

8. B.D. Bespartochnyj, A.V. Hromova, Izvestiya YUgo-Zapadnogo gosudarstvennogo universiteta 4(55), 117-122 (2014)

9. M.A. Zdorov, Vestnik RMAT 2(2), 82-83 (2011)

10. A.V. Truhachev, Konceptual'nye osnovy gosudarstvennoj politiki razvitiya sel'skogo turizma v Rossijskoj Federacii, dis. (SPb, 2017)

11. S. Phillip, C. Hunter, K. Blackstock, Tourism Management 31, 754-758 (2010)

12. T. Kizos, T. Iosifides, South European Society \& Politics 12.1, 59-77 (2007)

13. M.M. Markov, PhD Thesis. (SPb, 2009)

14. Dzh. O'Konnor, I. Makdermott, Iskusstvo sistemnogo myshleniya: neobhodimye znaniya o sistemah $i$ tvorcheskom podhode $k$ resheniyu problem (Al'pina Pablisher, Moscow, 2014) 